\title{
Mapping Out the Possible Outcomes of the Security Dilemma in International Politics
}

\author{
ER-WIN TAN ${ }^{*}$
}

\begin{abstract}
Whilst a significant amount of work has been undertaken in the field of security dilemma theory, there is a gap in the academic literature concerning the possible scenarios that may result from this phenomenon in international politics. To date, no known systematic attempt has been made to consider the full range of scenarios that may result from the security dilemma. Six possible scenario outcomes may be identified, these being: first, the security dilemma is transcended; second, a security-seeking state leaves itself unilaterally vulnerable to external aggression; third, the inappropriate adoption of diplomatic and military assertiveness to reaffirm deterrence instead arouses the fears of another security-seeking state, thereby leading to inadvertent escalation of a crisis into a conflict; fourth, a 'deep security dilemma' based on long-running mutual hostility that does not escalate into conflict; fifth, a security dilemma that escalates to the brink of conflict but is then de-escalated; and sixth, mitigation of the security dilemma between rival states. This article will explore these respective scenarios in terms of their underpinnings, as well as their implications for security and diplomacy.
\end{abstract}

Keywords: Security Dilemma Theory; Possible Scenarios, Brinkmanship, Risk of Conflict

*Associate Professor, Hankuk University of Foreign Studies, South Korea; E-mail: etango1979@gmail.com

DOI: $10.16934 /$ isr.20.1.201906.39 


\section{INTRODUCTION}

Ken Booth and Nicholas Wheeler describe how the security dilemma marks 'the quintessential dilemma' (Booth and Wheeler 2008, 2) at the heart of international politics. Since John Herz's coining of the concept (Herz 1950, 157), it has been elaborated on by a multitude of scholars. In light of continuing geostrategic tensions in international relations that have been described by various scholars as security dilemmas, the concept will continue to be of significant interest to the academic community. In particular, the growing geostrategic rivalry between the US and China, as well as the renewal of security competition between the US and Russia in recent years, underscore the continued relevance of the security dilemma as an academic concept in international relations.

However, additional research needs to be undertaken in order to examine the possible outcomes of the security dilemma for international politics. The rationale for such an undertaking is reflected in the eventual outcomes of the two, most-commonly cited, instances of the security dilemma, namely, the AngloGerman naval arms race in the early $20^{\text {th }}$ century and the US-Soviet nuclear arms race during the Cold War. Whilst the former culminated in the outbreak of the First World War (Tuchman 1962, 85-158), the latter was characterised by a decades-long standoff that culminated in rapprochement between Gorbachev and Reagan (Matlock 2004). This is further complicated by the fact that during the Cold War, two notable instances - the Cuban Missile Crisis of 1962 (Dobbs 2009) and the Able Archer nuclear war scare in 1983 (Hamilton 2018) - brought the US-Soviet security dilemma dangerously close to a nuclear exchange. It is the objective of this article to examine the range of possible scenario outcomes of the security dilemma in the following eight sections, with the first section providing a working definition of the security dilemma. In addition, this section will also incorporate discussion of the implications of Robert Jervis's discussion of the deterrence and spiral models as the key variables that influence the potential outcomes of the security dilemma. Based on this theoretical foundation, and as summarised in Table 1, it becomes possible to identify the following six possible outcomes of the security dilemma in international politics - each of these scenarios shall be examined in six separate sections. Based on this review of the possible scenario outcomes of the security dilemma in international politics, this article shall be brought to its conclusion. 


\section{TABLE 1. SECURITY DILEMMA OUTCOMES}

\begin{tabular}{|c|c|c|c|}
\hline & Scenario type & Pattern of interaction & Examples \\
\hline 1 & $\begin{array}{l}\text { Security dilemma } \\
\text { transcended }\end{array}$ & $\begin{array}{l}\text { Former rivals accept each other as friends and } \\
\text { partners in a security community }\end{array}$ & $\begin{array}{l}\text { Franco-German cooperation } \\
\text { within EU }\end{array}$ \\
\hline 2 & $\begin{array}{l}\text { Unilateral } \\
\text { Vulnerability to } \\
\text { Aggression }\end{array}$ & $\begin{array}{l}\text { Policymakers mistake aggressor state for } \\
\text { security-seeking state, adopt spiral model } \\
\text { axioms instead of deterrence ones. }\end{array}$ & $\begin{array}{l}\text { British 1930s appeasement } \\
\text { of Nazi Germany }\end{array}$ \\
\hline 3 & $\begin{array}{l}\text { The Security } \\
\text { Dilemma } \\
\text { Escalates into } \\
\text { Conflict }\end{array}$ & $\begin{array}{l}\text { Extremely high level of hostility between rival } \\
\text { powers; no possibility of long-term security } \\
\text { cooperation, but both sides believe that war is } \\
\text { imminent and that victory will go to the side } \\
\text { that attacks first. }\end{array}$ & $\begin{array}{l}\text { July Crisis of } 1914 \\
\text { escalation into World War } \\
\text { One }\end{array}$ \\
\hline 4 & $\begin{array}{l}\text { Deep Security } \\
\text { Dilemma }\end{array}$ & $\begin{array}{l}\text { Extremely high level of hostility between rival } \\
\text { powers; no possibility of long-term security } \\
\text { cooperation, but neither wants to initiate } \\
\text { conflict. Long-term hostility, stable deterrence. }\end{array}$ & $\begin{array}{l}\text { US-Soviet nuclear deterrence } \\
\text { for most of the Cold War }\end{array}$ \\
\hline 5 & $\begin{array}{l}\text { Security dilemma } \\
\text { escalates to brink } \\
\text { of conflict, but } \\
\text { both sides } \\
\text { de-escalate: four } \\
\text { variants }\end{array}$ & $\begin{array}{l}\text { Long-term hostility escalates, but both sides } \\
\text { back down rather than face a conflict that } \\
\text { neither wants. Four variants: } \\
\text { Variant 1: policy elites choose to back down } \\
\text { from crisis } \\
\text { Variant 2: retired statesmen mediate } \\
\text { de-escalation } \\
\text { Variant 3: third-party political leaders mediate } \\
\text { de-escalation } \\
\text { Variant 4: lower ranking officials recognize } \\
\text { danger of conflict, attempt to 'sabotage' } \\
\text { escalatory moves on own initiative }\end{array}$ & $\begin{array}{l}\text { Variant 1: Cuban Missile } \\
\text { Crisis, 1962. } \\
\text { Variant 2: Carter's talks in } \\
\text { Pyongyang, June 1994. } \\
\text { Variant 3: Moon Jae In's } \\
\text { mediation between Trump } \\
\text { and Kim Jong Un, 2018. } \\
\text { Variant 4: Able Archer War } \\
\text { Scare, 1983 }\end{array}$ \\
\hline 6 & $\begin{array}{l}\text { Security dilemma } \\
\text { mitigated }\end{array}$ & $\begin{array}{l}\text { Rival see each other as potential threats, but } \\
\text { recognize common interests in long-term } \\
\text { security cooperation, ie, security regime } \\
\text { between rival states }\end{array}$ & $\begin{array}{l}\text { Long-term diplomatic and } \\
\text { security cooperation within } \\
\text { Concert of Europe; Triple } \\
\text { Entente between UK, France } \\
\text { and Russia }\end{array}$ \\
\hline
\end{tabular}

Source: The author's own creation.

\section{THE SECURITY DILEMMA}

\section{Defining the Security Dilemma}

In coining the term 'security dilemma,' John Herz's contemplation of the implications of anarchy in international relations led to his observation that states are "driven to acquire more and more power in order to escape the impact of the power of others [rival states]. This, in turn, renders the others more insecure and compels them to prepare for the worst. Since none can feel entirely secure $\cdots$ power competition ensues, and the vicious circle of security and power accumulation is on" (Herz 1950, 157).

Writing at the same time, Herbert Butterfield identified the problem of 'Other Minds' as the psychological condition that may cause security-seekers to become hostile towards other security-seekers. Butterfield emphasised the role of 'Hobbesian Fear': "you yourself may vividly feel the terrible fear that you have 
of the other party, but you cannot enter into the other man's counter-fear' $\cdots$ you know that you yourself mean him no harm, and that you want nothing from him save guarantees for your own safety; and it is never possible for you to realise or remember properly that since he cannot see the inside of your mind, he can never have the same assurance of your intentions that you have" (Butterfield 1951, 21).

In more recent scholarship, Booth and Wheeler have further clarified the definition of the security dilemma as a 'two-level strategic predicament,' consisting of the dilemmas of interpretation and response (Booth and Wheeler 2008, 4-5). The dilemma of interpretation reflects the difficulty faced by policymakers in ascertaining if a rival's intentions are defensive (enhancing its own security), or offensive (ambitions of conquest). When policymakers resolve their dilemma of response in the belief that they are facing the latter, they assume that they face what Booth and Wheeler term a 'strategic challenge' (Booth and Wheeler 2008, 9). This leads to the dilemma of response - should a defensive state adopt a posture of restraint (diplomatic engagement and arms control) to reassure the other side, or one of firmness (visible military exercises and threats of military force) to reinforce deterrence (Booth and Wheeler 2008, 4-5).

Both courses of action carry risks, as illustrated by the crises that preceded the World Wars. During the Sudetenland Crisis of 1938, British Prime Minister Neville Chamberlain adopted diplomatic restraint in response to Hitler's bullying of Czechoslovakia, believing that placating Hitler would avert war (Tharoor 2015). Instead, by demonstrating weakness, Chamberlain whetted Hitler's appetite for conquest, leading to the Nazi invasion of Poland the following year and the subsequent outbreak of the Second World War (Thornton 2011, 118). Yet, the converse risk is just as compelling, as a posture of assertiveness to affirm deterrence may instead arouse the other side's fears, causing it to lash out in desperation. This was illustrated by the July Crisis of 1914 following the assassination of Archduke Franz Ferdinand of Austro-Hungary. The various European powers - Austro-Hungary and Germany on one side, and Russia and France on the other - adopted increasingly belligerent postures in support of their respective alliance partners in the belief that assertiveness would cause the opposing bloc to back down (McMeekin 2013). In so doing however, the mobilization of their respective armies had the effect of convincing one another that war was imminent, thereby preventing diplomatic resolution of the crisis, which escalated into the First World War (Ibid.).

\section{Jervis and The Deterrence and Spiral Models}

In underlining the difficulty that policymakers face in ascertaining the underlying intentions of their rivals, Booth and Wheeler build on Robert Jervis's deterrence and spiral models. Jervis's introduction of the deterrence model is 
premised on the contingent scenario of a status quo state confronted with an aggressive, expansionist rival. The latter is likely to test the resolve of the former through incrementally expansionist measures with the long-term objective of geostrategically weakening the status quo state (Jervis 1976, 58-64). Under such circumstances, it is necessary for the status quo state to demonstrate firmness and resolve against the expansionist to underline that it will not be intimidated or coerced into backing down (Ibid.). Such policy measures may include an increase in its military budget and arms acquisitions, the strengthening of its alliance relations and clearly-stated diplomatic statements warning the expansionist state that continuation of its provocative behaviour will be punished by the status quo state (Ibid.). In this sense, the status quo state has to demonstrate clear resolve and willingness to go to war to defend itself and its allies against its rival. Even minor concessions to the rival must be ruled out, lest such a reconciliatory posture be taken by its rival as a sign of weakness that can be exploited (Ibid.). In so doing, the status quo state's adoption of deterrence model axioms ensures that it is in a stronger position to deter its rival from engaging in further aggressive expansionist behaviour, or, if such deterrence fails, ensures that the status quo state has a more robust military for the purpose of defending itself from its rival (Ibid.).

At the same time, Jervis put forward an alternative perceptual framework that considers the implications of Butterfield's writings about Hobbesian fear in international relations. As Jervis notes, "the underlying problem lies in $\cdots$ a correct appreciation of the consequences of living in a correct appreciation of the consequences of living in a Hobbesian state of nature" (Jervis 1976, 62). In the anarchic world of international relations, the absence of world government causes states to turn to self-help, in the form of arming themselves, in order to ensure their own security. Even in the absence of a clear threat to their security, there is little to guarantee that such a benign environment will endure indefinitely. Under such circumstances, prudent policymakers take worst-case scenarios into account, as reflected in the continued acquisition of arms even in the absence of a clear security threat (Ibid.). Yet, as the condition of anarchy affects multiple states, the actions of any one state, in attempting to increase its own security through acquiring more armaments, may arouse its neighbours' fears that such military expansionism is being driven by offensive intentions (Jervis 1976, 64-68). With similar fears for their own security, these states find themselves engaged in similar arms acquisitions and belligerent diplomatic posturing (Ibid.). Amidst the backdrop of anarchy, the resulting arms racing and diplomatic belligerence causes mutual antagonism and hostility to spiral into a self-fulfilling prophecy (Ibid.).

Although Jervis introduced the deterrence and spiral models some 30 years before Booth and Wheeler emphasised the dilemmas of interpretation and response as the variables at the heart of the security dilemma, it is apparent that 
Booth and Wheeler are building on Jervis's earlier work. As they note, "the task facing governments $\cdots$ [is] to decide whether they are in a spiral or deterrent situation, and then to adopt the appropriate policies" (Booth and Wheeler 2008, 48). This challenge is underscored by the fact that policymakers do not have the benefit of hindsight in ascertaining the underlying intentions of their rival, but must nonetheless formulate diplomatic and security policies that seek an optimum outcome against a prospective rival.

\section{Payoffs of the Deterrence and Spiral Model}

Such dynamics are encapsulated in the game theory matrix in Table 2. A and B Payoffs in the Security Dilemma, in which the numbers in the boxes being the payoff for A and B should they adopt deterrence or spiral model axioms in their interaction with one another.

\section{TABLE 2. A AND B PAYOFFS IN THE SECURITY DILEMMA}

\begin{tabular}{|c|c|c|}
\hline & If $A$ is facing spiral model with $B$ & If $A$ is facing deterrence model with $B$ \\
\hline $\begin{array}{l}\text { A's cooperative move } \\
\text { to B: adopt spiral } \\
\text { model axioms }\end{array}$ & $\begin{array}{l}\text { Payoff for A: } 9 \\
\text { Payoff for B: } 9 \\
\text { 'Mutual Cooperation for Mutual } \\
\text { Benefit': both sides recognise one } \\
\text { another's security concerns, seek to } \\
\text { assure one another }\end{array}$ & $\begin{array}{l}\text { Payoff for A: } 1 \\
\text { Payoff for B: } 9 \\
\text { 'Unilateral Vulnerability': A loses } \\
\text { credibility of deterrent posture, whets } \\
\text { B's appetite for easy conquest }\end{array}$ \\
\hline $\begin{array}{l}\text { A's defection from } \\
\text { cooperation against } \\
\text { B: adopt deterrence } \\
\text { model axioms }\end{array}$ & $\begin{array}{l}\text { Payoff for A: } 1 \\
\text { Payoff for B: 1 } \\
\text { 'Mutual Loss': A's adoption of } \\
\text { deterrence model axioms arouses B's } \\
\text { fears, causes B to lash out in } \\
\text { desperation; unintended conflict } \\
\text { between security-seeking states }\end{array}$ & $\begin{array}{l}\text { Payoff for A: } 9 \\
\text { Payoff for B: } 1 \\
\text { 'Strong Defense': A has stronger } \\
\text { deterrent and defense capability } \\
\text { against B; B's ambitions of easy } \\
\text { conquest thwarted }\end{array}$ \\
\hline
\end{tabular}

Source: The author's own creation

In the most desirable outcome, both $\mathrm{A}$ and $\mathrm{B}$ recognise one another as fellow security-seekers facing a spiral model with one another, and work cooperatively to assuage their respective security concerns, hence the high payoff of 9 for both A and B that results from their mutual cooperation in leading to a 'win-win' solution for both. Their adoption of spiral model axioms in the form of diplomatic restraint and arms control measures to address their respective security fears would enable a de-escalation of the tensions in their relationship. Inasmuch as mitigation of the security dilemma is possible, such an outcome was reflected in how the rapprochement between Mikhail Gorbachev and Ronald Reagan led to the end of the Cold War (Kydd 2000, 344-48). Moreover, the possibility that erstwhile rivals may transcend the security dilemma was reflected in how, despite centuries of rivalry and security competition, France and Germany were, in the aftermath of 1945 , able to forge the foundations of the transatlantic security 
community (Wheeler 2018, 123-25).

Although this represents the best possible result of the adoption of spiral model axioms, such outcome is dependent on being adopted appropriately within the context of a spiral situation. As noted in how Booth and Wheeler emphasised the challenge faced by policymakers in seeking an optimum course of action amidst the condition of uncertainty in international politics without the benefit of hindsight, states do not know if their counterpart has defensive intentions or aggressive ones (Booth and Wheeler 2008, 30-34). Were A to adopt spiral model axioms when $\mathrm{B}$ is, in fact, an aggressive expansionist - in other words, a deterrence model situation - A's diplomatic restraint will convince B that A lacks resolve and can be taken advantage of (Jervis 1976, 85). This is reflected in the very high payoff of 9 for $\mathrm{B}$ and the very low payoff of 1 for $\mathrm{A}$, in which an untrustworthy B exploits A's attempt at cooperation. Under such circumstances, B's appetite for conquest is likely to be encouraged in the belief that it does not face opposition to its ambitions of conquest and expansionism.

The prospect of unilateral vulnerability thus gives a compelling reason for A to favour deterrence model axioms against B. Rather than accept the outcome of being exploited by what may be an untrustworthy B, A would instead respond to $\mathrm{B}$ through the adoption of deterrence model axioms, such as arms acquisitions and diplomatic assertiveness, to convey resolve and to strengthen itself against B. This is reflected in the very high payoff of 9 for A and the very low payoff of 1 for B. A is able to demonstrate a clear, credible deterrent capability against B, thereby thwarting B's ambitions for easy expansionism. Moreover, by demonstrating resolve, $\mathrm{A}$ is able to affirm its credibility as an alliance partner against other states that may be concerned about B's expansionism. Even if deterrence should fail, A's adoption of deterrence model axioms leaves it in a militarily stronger position - having sought to enhance its military capabilities and mobilised allies, $\mathrm{A}$ is in a stronger strategic position from a more effective defense against an expansionist B can be implemented. Thus, for instance, if Chamberlain had responded to Hitler's expansionist behaviour during the Sudetenland Crisis of 1938 by explicitly threatening military intervention in support of France and Czechoslovakia, it might have induced caution in Berlin over its ambitions to dominate Europe (Ferguson 2006). Even if a more assertive British posture failed to deter Nazi expansionism over the long term, it would have functioned as a more credible rallying point to form an anti-Nazi alliance in Europe that would have nipped Nazi ambitions of conquest in the bud (Ibid.).

At the same time, however, deterrence model axioms would be erroneous if it turns out that $\mathrm{A}$ is, in fact, facing a spiral situation with $\mathrm{B}$. This is reflected in the low payoffs that $\mathrm{A}$ and $\mathrm{B}$ both stand to derive through the adoption of deterrence model axioms when they are in fact facing a spiral model situation. A, by adopting deterrence model axioms, inadvertently arouse B's fears that its own 
security interests are being threatened. In the event that B similarly fails to appreciate A's fears, B lashes out in desperation against what it perceives to be A's bullying behaviour. Yet, failing to recognise how its own actions have caused B to become fearful in the first place, A believes that B's hostile response reflects B's status as an aggressive power. Under such circumstances, A believes that further adoption of deterrence model axioms is necessary to further communicate resolve in an attempt to intimidate B into backing down. In so doing, both sides, by simultaneously adopting deterrence model axioms against one another whilst failing to recognise the spiral model of escalating mutual hostility hat they are both contributing to, cause their hostility to turn into a self-fulfilling prophecy, as reflected in how the mutual defection of $\mathrm{A}$ and $\mathrm{B}$ on each other has resulted in the extremely low payoff of 1 .

Such dynamics were reflected during the July Crisis of 1914. In the aftermath of the assassination of Archduke Franz Ferdinand and the escalating tensions, the various European powers - primarily France and Russia on the one hand, ${ }^{1}$ and Germany and the Austro-Hungarian Empire on the other - adopted deterrence model axioms in the form of mobilising their armies for war in the belief that such shows of force would intimidate the opposing side into backing down (McMeekin 2013). Instead, by convincing one another that war was increasingly imminent, the inappropriate adoption of deterrence model axioms in what, in hindsight, was a spiral model situation, had the effect of further causing the July Crisis to escalate into the outbreak of the First World War (Ibid.). Thus, it is apparent that the July Crisis of 1914 and the Sudetenland Crisis of 1938 function as ideal representative scenarios that reflect the risks that policymakers face in adopting deterrence and spiral models. Yet, the two crises represent only two possible outcomes of the security dilemma. As indicated in the following sections, other interactions in history and international relations may also be characterised as security dilemmas, yet have outcomes that are not neatly encapsulated in the aforementioned scenarios. Particularly useful in this regard are the security dilemmas faced in US-Soviet interaction during the Cold War, and between the US and North Korea, as the decades-long interactions of both instances provide a wealth of empirical data for analysis of the implications of the security dilemma.

The range of these possible outcomes summarised in Table 1, Security Dilemma Outcomes, thus requires further elaboration. For the purpose of illustrating these scenarios, the typology of States A and B shall be reused, albeit with differing circumstances in each of these scenarios that illustrate my conceptual argument. In illustrating these scenarios, it is necessary to emphasise that, although several of the empirical instances selected have been cited by various scholars as security dilemmas, such interpretations are not universally accepted. Thus, for instance, in citing the July Crisis of 1914 as an instance of the 
security dilemma, I am aware that the late Fritz Fischer would reject such an analysis - in Fischer's view, World War One resulted from deliberate German brinkmanship to escalate the crisis into a war that would enable German dominance of Europe (Fischer 1967, 88). Even more contentious is the citation of Chamberlain's appeasement of Hitler. Hitler's ambition to dominate Europe through conquest is not in question (Braunbeck 1997, 3-4). Rather, this example illustrates Chamberlain's inappropriate adoption of spiral model axioms in a misguided bid to avert war, when - and with the benefit of hindsight that Chamberlain did not have in 1938 - deterrence model axioms would have been more appropriate.

Whilst this selection of empirical instances may be debated, the purpose of the following sections is to cite historical episodes that illustrate the implications of appropriate diplomatic security policymaking amidst the existential condition of uncertainty in international relations. If such a selection of empirical examples is subject to historical debate, it may be helpful to bear in mind the observation of Booth and Wheeler that 'what history tells us are things over which historians agree or disagree, not what actually happened' (Booth and Wheeler 2008, 10). Insofar as this article's efforts to identify the implications of the security dilemma are concerned, the below-cited instances of diplomatic and security policymaking amidst the existential condition of uncertainty in international relations suffices for this purpose.

\section{SCENARIO 1: THE SECURITY DILEMMA TRANSCENDED²}

In emphasising the potentially transformative role of trust in interaction between human beings, Booth and Wheeler describe the impact of security communities, amongst whose members accept that war between themselves has become 'unthinkable' (Booth and Wheeler 2008, 296). Trust may become sufficiently internalised in their relationship that they no longer have any reason to regard one another's armaments as threatening. Under such circumstances, their respective military capabilities lose any significance in one another's national security calculations.

Such a situation describes the current level of diplomatic and security cooperation between France and Germany as the leading powers within the European Union. The two had engaged in centuries of rivalry and war against one another, with particular intensity from the French Revolution in 1789 until the Second World War. Yet, in spite of this longstanding legacy of war and rivalry, the leaders of post-1945 Europe were able to forge to forge the foundations of diplomatic and security cooperation that underpins the contemporary European Union (EU) (Koenig and Walter-Franke 2017). Particularly notable in this regard was the vision of French Foreign Minister Robert Schuman who, just six years 
after the end of the Second World War, called for reconciliation with the Federal Republic of Germany as a fellow founding member of the European Coal and Steel Community (ECSC) (Lee 2004). Although Franco-German relations in 1951 remained cautiously based on calculations on the possibility of defection (Jo 2007, 55-70), the growing spirit of cooperation led to the emergence of embedded levels of interpersonal trust between French and German leaders (Booth and Wheeler 2008, 192-96). The underlying political foundations of France and Germany as former rivals that have transcended security dilemma remains sound, as the prospect of their returning to security rivalry against each other is unthinkable in the present day (Ibid.).

Although Scenario 1 is an ideal outcome inasmuch as it envisages the possibility that erstwhile rivals in international politics may be reconciled, such occurrences are uncommon. If anything, it is possible that the instance of Franco-German reconciliation may go down in history as an anomaly due to two variables in the post- 1945 world order that are unlikely to be replicated for the foreseeable future, these being, first, the Soviet military presence in Eastern Europe as a common enemy to Western Europe, and second, the US security commitment to Europe under NATO (Ripsman 2005, 674-681). If anything, the period of rapprochement between Reagan and Gorbachev during the late 1980s has since been replaced by renewed geostrategic US-Russian competition since Vladimir Putin's rise to power, thereby underscoring the difficulties faced in sustaining rapprochement between rivals for power and security in international politics. Such challenges are all the more apparent in light of the other possible outcomes of the security dilemma examined below.

\section{SCENARIO 2: UNILATERAL VULNERABILITY TO AGGRESSION}

This describes a situation in which policymakers in A mistakenly assume that B's armaments are defensive, when in reality B is secretly planning aggressive expansionism. This leads to the game theory matrix in Table 3, Unilateral Vulnerability to Aggression.

\section{TABLE 3. UNILATERAL VULNERABILITY TO AGGRESSION}

\begin{tabular}{lll}
\hline & $\begin{array}{l}\text { Spiral model axioms: } \\
\text { payoff for A }\end{array}$ & $\begin{array}{l}\text { Deterrence model axioms: } \\
\text { payoff for A }\end{array}$ \\
\hline $\begin{array}{l}\text { A's assumption that B is a security } \\
\text { seeker }\end{array}$ & 9 & 1 \\
\hline $\begin{array}{l}\text { The reality that B is an aggressive } \\
\text { expansionist }\end{array}$ & 1 & 9 \\
\hline
\end{tabular}

Source: The author's own creation 
A, lacking hindsight and mistaking B for a security-seeker, assumes that the optimum course of action during the immediacy of a crisis is to adopt spiral model axioms in a bid to seek reconciliation with $\mathrm{B}$, whilst assuming that deterrence model axioms would have the effect of causing B to lash out (Booth and Wheeler 2008, 5). Instead, A believes that the adoption of spiral model axioms in the form of diplomatic restraint offers a significantly better prospect of a better payoff of 9 by averting outbreak of war due to A's assumption that B is a security seeker. Yet, A's inappropriate adoption of spiral model axioms in a misguided attempt to avert conflict instead conveys an impression of weakness, thereby convincing B that aggressive expansionism will be unopposed and whetting B's appetite for further conquest (Jervis 1976, 58-59). With the benefit of hindsight, A should adopt deterrence model axioms to reinforce its deterrent posture against $\mathrm{B}$, as indicated in the high payoff of 9 that would result; conversely, given that spiral model axioms would be seen by B as evidence of A's lack of resolve, such a course of action should be avoided by A (Ibid.).

Such a course of action is rather more difficult to implement in practice, as reflected in the aforementioned instance of Chamberlain's appeasement of Hitler. Although Chamberlain has been heavily criticized by historians for this episode, it should be recalled that he did not have the benefit of hindsight in identifying Hitler's intentions. If Chamberlain had the benefit of hindsight in 1938, he would have likely adopted a more assertive posture in supporting France and Czechoslovakia to present a united front against Hitler in 1938. As Chamberlain noted, "it would be a tragic blunder [for our enemies] to mistake our love of peace' ${ }^{\prime}$ for weakness" (Chamberlain, cited in Jervis 1976, 96). Indeed, when Hitler's invasion of Poland in 1939 made the expansionist nature of Nazi Germany blatantly clear, Chamberlain was prepared to declare war in response (Tharoor 2015).

In revealing the dangers of mistakenly adopting spiral model axioms when deterrence model ones would be more appropriate, the implications of Scenario 1 have been cited by conservative scholars and policymakers to warn of the danger of unilateral vulnerability to aggression. Yet, without downplaying the significance of Hitler as an aggressive expansionist, the historical record indicates that such statesmen are anomalies. As Thomas Christensen noted, "most revisionist actor $\mathrm{s} \cdots$ have been deterrable $\cdots$ for the simple reason that these actors placed a higher value on things other than conquest" (Christensen 2002, 9). As indicated in the following sections that discuss Scenarios 3, 4, 5 and 6, there are multiple scenarios that reflect the implications of spiral model axioms in international relations. This is further complicated by the fact that the range of possible outcomes of the security dilemma is rather more complicated than a binary choice between transcending the security dilemma on the one hand, and facing unilateral vulnerability to an aggressor on the other. 


\section{SCENARIO 3: THE SECURITY DILEMMA ESCALATES INTO CONFLICT}

Scenario 3 denotes a situation in A and B are both security-seeking states facing a spiral model situation with each other, whilst simultaneously failing to appreciate the nature of their predicament and instead believing that they are facing a deterrence model situation. Such an outcome is particularly serious when both $\mathrm{A}$ and $\mathrm{B}$ subscribe to belief in offence-dominance, or the assumption that offensive military doctrines and technology are advantageous (Jervis 1978, 205, Lynn Jones, 1995). This is evident in the game theory matrix in Table 4, The Security Dilemma Escalates into Conflict.

\section{TABLE 4. THE SECURITY DILEMMA ESCALATES INTO CONFLICT}

\begin{tabular}{lll}
\hline & Deterrence Model axioms & Spiral Model axioms \\
\hline $\begin{array}{l}\text { A and B perceive each other as } \\
\text { aggressive expansionists }\end{array}$ & Payoff for A: 9 & Payoff for A: 1 \\
\hline $\begin{array}{l}\text { The reality that A and B are } \\
\text { security-seekers }\end{array}$ & Payoff for B: 9 & Payoff for B: 1 \\
\hline
\end{tabular}

Source: The author's own creation

Because both A and B subscribe to assumptions of offence-dominance (Jervis 1978, 2011), both conclude that the deterrence model axioms, such as early offensive military action against the other to deliver a knockout blow at the start of a conflict, offers the highest payoff, 9. The same assumption of offence-dominance also cause both A and B to believe that any attempt to adopt spiral model axioms, such as diplomatic restraint in a bid to de-escalate tensions, would leave them unilaterally vulnerable to their rival's defection from cooperation (i.e., the assumption that their rival is on the verge of initiating offensive military action), hence the extremely low payoff of 1 . At the same time, however, such calculations hold validity only if both A and B are actually facing a deterrence model situation. When they are, in fact, facing a spiral model situation, the inappropriate adoption of deterrence model axioms constitutes mutual defection by both A and B against each other, hence the extremely low payoff of 1 for both parties. If both sides are able to acknowledge the spiral model in their interaction and respond accordingly by both adopting restraint to de-escalate a crisis and hence avert war, they would both receive the extremely high payoff of 9 .

Such dynamics were reflected in how the July Crisis of 1914 escalated into the First World War, following the assassination of Archduke Franz Ferdinand of the Austria Hungarian Empire. None of the European powers in July 1914 was particularly enthusiastic for a major European conflagration. 
Nonetheless, the absence of a brake against war was reflected in what Stephen Van Evera referred to as the 'Cult of the Offensive' amongst European generals and statesmen (Van Evera 1984, 58-60). Guided by a combination of jingoism, wishful thinking and a misplaced belief in the superiority of offensively-oriented military doctrines, the majority of European policymakers were convinced that victory required them to mobilise their armies as quickly as possible in a crisis. In conjunction with the then-prevailing assumptions that the efficient deployment of reinforcements to the frontlines was dependent on close coordination with their train schedules (Tuchman 1962, 94-95), this meant that the various European leaders who blundered into war opposed delaying the orders for mobilization for their respective armies, even if such an action might have enabled a diplomatic de-escalation of the crisis, given their assumption that war was already inevitable and unavoidable (McMeekin 2013, 288-305).

\section{SCENARIO 4: THE DEEP SECURITY DILEMMA}

Yet, states' adoption of inappropriate policy responses to the security dilemma does not necessarily lead to the outbreak of conflict described in scenarios 2 and 3. Particularly illuminating in this regard was Jervis's coining of the "deep security dilemma $\cdots$ [in which] both sides may be willing to give up the chance of expansion if they can be made secure, but a number of other factors $\cdots$ put such a solution out of reach" (Jervis 2001, 41). Thus, although both sides have defensive intentions, the extent of their mutual hostility is so deeply embedded that neither is willing to take the first step in de-escalating the security dilemma. Even though A and B have a limited appreciation of spiral model dynamics in their interaction with each other, their defence planning is nonetheless trumped by the prioritisation of deterrence model axioms. Nonetheless, and in contrast to Scenario 3, the fact that both A and B possess formidable military capabilities whose lethality they are aware of, they recognise that armed conflict against one another would constitute mutual suicide. Both sides are more likely to maintain a posture of deterrence against the other, whilst avoiding unnecessary provocations against the other side. This is reflected in the game theory matrix in Table 5. The Deep Security Dilemma.

TABLE 5. THE DEEP SECURITY DILEMMA

\begin{tabular}{lll}
\hline & Deterrence model axioms & Spiral model axioms \\
\hline Payoff for A & 7 & 6 \\
\hline Payoff for B & 7 & 6 \\
\hline
\end{tabular}

Source: The author's own creation 
A and B are both security seekers and are aware of the moderately high payoff of 6 that they stand to derive from adopting spiral model axioms in order to mitigate the spiral model in their interaction. Nonetheless, as reflected by the marginally higher payoff of 7 that they would receive by adopting deterrence model axioms, neither side is prepared to make the first move due to the fear felt by both sides that adoption of spiral model axioms would be seen by their rival as a sign of weakness, and hence an easy opportunity for expansionism. Because both $\mathrm{A}$ and $\mathrm{B}$ anticipate their rival engaging in such defection from cooperation, neither side is willing to take the first move in adopting spiral model axioms for fear that their attempt at cooperation will be exploited. Under such circumstances, both A and B believe that they stand to derive a slightly higher pay off by adopting deterrence model axioms instead of spiral ones. Whilst the security dilemma is likely to be characterized by significant hostility, it is also unlikely to escalate into high-intensity conflict. It should, however, be noted that this does not preclude such actions as espionage and low-intensity armed provocations that fall below the threshold of all-out war. In addition, the emergence of aggressive new leaders, the introduction of new classes of weaponry, or a leadership's miscalculation, may cause a deep security dilemma to escalate into the more pessimistic scenarios discussed elsewhere in this article.

The dynamics of the deep security dilemma were evident in the logic of Mutually Assured Destruction (MAD) during the US-Soviet nuclear arms race. During the early years of the Cold War, the US and USSR relied on nuclear bombs to be deployed from bomber aircraft, as well as liquid-fuelled Inter-Continental Ballistic Missiles (ICBMs) (Jervis 1978, 211-214). Such assets operated from vulnerable fixed bases and required significant amounts of preparation time before they could be deployed, making them highly vulnerable to a pre-emptive nuclear 'First Strike' by the other side (Ibid.). By the 1970s, however, both the US and USSR had developed 'Second-Strike' nuclear capabilities. The development of SLBMs meant that both the US and USSR were able to deploy their warheads aboard submarines that would survive an enemy 'First Strike' and launch their nuclear missiles (Ibid.). Both the US and USSR were fully aware that any 'First Use' of nuclear warheads against the other would be met by the retaliatory 'Second Strike' launch of their adversary's SLBMs (Ibid.). Under such circumstances, the logic of MAD meant that neither side had any interest in deliberately engaging in unnecessary brinkmanship (Muller 2004, 45-46). 


\section{SCENARIO 5: DE-ESCALATION OF THE SECURITY DILEMMA FROM THE BRINK}

In addition, escalation of the security dilemma into conflict is not a foregone conclusion. Numerous instances from history reflect situations in which tensions between rival states have escalated to the brink of conflict; nonetheless, both sides, recognising that all-out war is too perilous an outcome to risk, choose to back down. Whilst such an outcome will likely leave both sides remaining deeply hostile towards one another (as per the dynamics of a deep security dilemma), the shared recognition of how close they had come to war will likely induce caution, at least in the immediate aftermath of a near-war crisis. In this sense, whilst A and B have deeply internalised deterrence model assumptions about one another, both sides are also aware, to a limited degree, of the possibility that spiral model dynamics may be shaping their interaction. In this, their limited recognition of spiral model interaction is not due to any recognition of their rivals' security fears, but rather the shared realization that their mutual adoption of increasingly belligerent deterrence model axioms is bringing both of them dangerously close to the brink of a conflict that neither side really wants. Such a scenario closely resembles Scenario 3 inasmuch as A and B fail to appreciate the spiral model that is driving their interaction; however, Scenario 5 is differentiated by the presence of entity $\mathrm{C}$, denoting an entity that is more sensitive to the predicament that $\mathrm{A}$ and $\mathrm{B}$ face as a result of their inability to appreciate spiral model dynamics in their interaction. This is reflected in the game theory in Table 6. De-Escalation of the Security Dilemma from the Brink.

\section{TABLE 6. DE-ESCALATION OF THE SECURITY DILEMMA FROM THE BRINK}

\begin{tabular}{lll}
\hline Spiral Model axioms & Deterrence Model axioms & Spiral Model axioms \\
\hline $\begin{array}{l}\text { A and B perceive each other as } \\
\text { aggressive expansionists }\end{array}$ & Payoff for A: 7 & Payoff for A: 3 \\
\hline $\begin{array}{l}\text { The reality that A and B are } \\
\text { security-seekers }\end{array}$ & Payoff for B: 7 & Payoff for B: 3 \\
\hline $\begin{array}{l}\text { C's sensitivity to spiral model interaction for A: 3 } \\
\text { between A and B }\end{array}$ & Payoff for B: 3 & Payoff for A: 7 \\
\hline
\end{tabular}

Source: The author's own creation

In such a scenario, $\mathrm{A}$ and $\mathrm{B}$ perceive deterrence model axioms as yielding a payoff of 7 - high, but not as high as in Scenario 3; conversely, A and B perceive a payoff of 3 should they adopt spiral model axioms - low, but not as a low as in Scenario 3. Under such circumstances, although neither side is particularly enthusiastic for war, the reluctance of both sides to appear weak in the eyes of their rival causes them to favour deterrence model axioms, even if this is causing them both to play the Game of Chicken to the brink of a conflict 
(Schelling 1966, 116). At the same time, however, because neither side appreciates the implications of the spiral model, A and B both fail to realise that a moderately high payoff of 7 can be attained should they exercise restraint. As A and B are deeply hostile towards one another, both fear that being the first to make concessions to the other would be a sign of weakness that would damage their longer-term interests. Neither side therefore is willing to take the first step in de-escalating the crisis. Under such circumstances, there is a risk that a given standoff may escalate into armed conflict (Nalebuff 1986, 21-22). Yet, within the same situation, there may be other entities, designated by the placeholder $\mathrm{C}$, that are more sensitive to spiral model dynamics in the interaction between $\mathrm{A}$ and $\mathrm{B}$. $\mathrm{C}$ recognises that, without a brake on spiral model interaction between $\mathrm{A}$ and $\mathrm{B}$, the security dilemma runs the risk of escalating into armed conflict, hence the low payoff for $\mathrm{C}$ of 3 (as well as C's understanding that $\mathrm{A}$ and $\mathrm{B}$ too will suffer a payoff of 3), should A and B continue to subscribe to deterrence model axioms. Under such circumstances, $\mathrm{C}$ may choose to intervene directly and enter the fray, attempting to function as a third-party brake against spiral model interaction between $\mathrm{A}$ and $\mathrm{B}$, for instance by mediating a de-escalation of a given security dilemma, or refusing to follow existing directives that, if carried out, run the risk of escalation into conflict. Yet, because $\mathrm{C}$ is only tangentially involved in the interaction between $\mathrm{A}$ and $\mathrm{B}$, it can only mediate a de-escalation of the security dilemma; given the overall backdrop of hostility between A and B, C's mediation alone is unable to lead to significant transformation in the overall pattern of hostility and rivalry between A and B. Four sub-variants of Scenario 5 can be identified; these are discussed in the following sub-sections.

\section{Scenario 5.i Political Leaders Step Away From Brink}

In the first variant of Scenario 5, policymakers in rival states may escalate a crisis to the brink of war, but then back down when they realise that once war breaks out, it will be impossible to de-escalate. Such an episode was reflected in role of Attorney-General Robert Kennedy in establishing a critical backchannel between the White House and the Soviet Ambassador in Washington, Anatoly Dobrynin. During the early stages of the crisis following the US discovery that the USSR was deploying nuclear missiles to Cuba, the hawkish Secretary of State, Dean Rusk and CIA Director John McCone had called for airstrikes to destroy the growing Soviet military presence in Cuba (Polmar and Gresham 2006, 105-07).

Yet, despite the rapidly escalating tensions, the growing recognition of the risk of an all-out nuclear exchange between the US and the USSR alarmed both sides into seeking a negotiated de-escalation (Polmar and Gresham 2006, 186-88). Into the fray came the role of the younger Kennedy in establishing a 
backchannel between the White House and Dobrynin, during which the younger Kennedy was able to privately assure his Soviet counterpart of the Kennedy Administration's pre-existing US plans to withdraw its Jupiter nuclear missiles from Turkey (Ibid.). This was crucial in functioning as a 'sweetener' for Soviet withdrawal of its nuclear missiles from Cuba (Ibid.). Yet, whilst the US and USSR walked away from the crisis shaken about how close they had come to a nuclear exchange, the underlying ideological hostility of the Cold War remained. Thus, the shared recognition of how narrowly nuclear world war had been averted was a significant factor behind their efforts to limit nuclear proliferation to the existing club of nuclear powers, leading to the Nuclear Non-proliferation Treaty in 1968 (Schlosser, 2018). Nonetheless, Cold War rivalry and hostility continued, as reflected in the US and USSR undertaking continued development and upgrading of their nuclear arsenals well into the 1970s and 1980s, including the development of Submarine Launched Ballistic Missiles (SLBMs), Multiple Independent Re-Entry Vehicles (MIRVs) and cruise missiles (Frye 1984).

\section{Scenario 5.ii Retired Statesmen Mediate De-Escalation}

In Variant ii of Scenario 5, A and B are rival states on a collision course for a conflict. The leaders of A and B are both unwilling to take the first step in de-escalating the crisis (as per spiral model axioms) for fear of being seen as weak-willed against their adversary. Nonetheless, war might still be averted through retired statesmen who offer their services to mediate de-escalation of a standoff (Princen 1995, 50-51). The position of such intermediaries is particularly influential when they are considered respected Elder Statesmen with a track record of even-handedness by both sides facing the security dilemma (Ibid.).

This was demonstrated during the 1994 North Korean nuclear crisis. In June 1994, in response to North Korea's unloading of the gas-graphite reactor at Yongbyon - an action that would have enabled Pyongyang to commence separation of plutonium for the purpose of producing nuclear weapons (Wit, Poneman and Gallucci 2004, 169-70) - the Clinton Administration began planning airstrikes to destroy the Yongbyon reactor (Wit, Poneman and Gallucci 2004, 208-20). Such action would have resulted in North Korean retaliation against the ROK and a war on the Korean Peninsula (Oberdorfer and Carlin 2014, 255-56). Amidst these tensions, former US President Jimmy Carter visited Pyongyang for talks with North Korean Supreme Leader Kim Il Sung, during which he was able to explore the opportunities for the US and North Korea to step away from the brink (Creekmore 2006, 155-246). By averting the rush to war, Carter's talks enabled the resumption of US-North Korean negotiations that led to the signing of the Agreed Framework in October 1994 (Wit, Poneman and Gallucci 2004, 251-327), under which North Korea agreed to suspend activity at 
the Yongbyon nuclear reactor in exchange for US economic and energy aid (Creekmore 2006, 301-30). Nonetheless, as reflected in the difficulties faced in the implementation of the Agreed Framework and North Korea's subsequent continuation of nuclear activity, Carter's talks did not resolve the underlying tensions between the US and North Korea (Oberdorfer and Carlin 2014, 319-321).

\section{Scenario 5.iii Third Party Leaders Mediate De-Escalation}

In Variant iii of Scenario 5, political leaders of third party states with a stake in regional stability fear the prospect of being enveloped in a rapidly escalating crisis, and may attempt to mediate a de-escalation of tensions. The plight of such leaders is all the more accentuated when they face the prospect of their national soil becoming the battleground where the security dilemma escalates into armed conflict, even as they recognise the impact of spiral model axioms between $\mathrm{A}$ and $\mathrm{B}$.

Such a scenario was illustrated in ROK President Moon Jae In's efforts to de-escalate US-North Korea tensions in 2018. In response to multiple North Korean missile tests and a nuclear test, US President Donald Trump entered into a vicious 'war of words' with North Korean Supreme Leader Kim Jong Un (BBC 2018). Faced with the prospect of a conflict that would have entangled the ROK due to its alliance with the US, Moon used the occasion of the 2018 Winter Olympics to hold a series of summits with Kim Jong Un with a focus on inter-Korean reconciliation (Snyder and Byun 2018), whilst simultaneously playing to Trump's ego by suggesting that the US President be nominated the Nobel Peace Prize for not going to war against North Korea (Ignatius 2018). The ROK President's sensitivity to spiral model dynamics between the US and North Korea was crucial in defusing a situation that Van Jackson noted stood on the brink of conflict (Jackson 2018, 132-49). Yet, whilst the period since the 2018 Singapore Summit between Trump and Kim Jong Un saw a marked de-escalation in US-North Korean tensions, it should be noted that underlying suspicion remains high, as reflected in the failure of the more recent Kim-Trump Summit in Hanoi in 2019 (Salmon 2019).

\section{Scenario 5.iv Lower Ranking Officers 'Sabotage' the Rush to War}

In this variant of Scenario 5, war may be averted by lower-ranking diplomatic and military officials who block actions which they recognize risk escalation into conflict. Such officials recognize the implications of spiral model axioms, even if their superiors do not. Under such circumstances, they may choose, on their own initiative, to take actions to de-escalate the crisis, even if 
such actions run contrary to their supervisors' instructions (Cohn 2017). This was illustrated in during the tensions surrounding the Able Archer NATO military exercise in 1983, when Soviet radar mistook an unusual cloud formation over North America as a US nuclear missile launch against the USSR (Aksenov 2013). The Soviet duty officer, Lieutenant-Colonel Stanislav Petrov, recognised a false alarm and chose not to alert his superiors (Ibid.). Had Petrov followed his standard instructions and passed the apparent missile launch warning to his superiors, the backdrop of Cold War tensions would have likely led to the Soviet leadership responding by initiating nuclear attacks on the US, thereby leading to full-scale thermonuclear war (Ibid.).

\section{SCENARIO 6: THE SECURITY DILEMMA MITIGATED}

In this scenario, $\mathrm{A}$ and $\mathrm{B}$ recognize that it is in their common interests to institutionalise a limit to reduce their security competition against one another, thereby mitigating the security dilemma. Whilst the perception that they are rivals for security remains (thereby reflecting continued internalization of deterrence model axioms), the mutual recognition that they may be facing spiral model interaction contributes to both sides' efforts to accommodate their respective security concerns. This is illustrated in the game theory matrix in Table 7 . The Security Dilemma Mitigated.

TABLE 7. THE SECURITY DILEMMA MITIGATED

\begin{tabular}{ccc}
\hline & Deterrence model axioms & Spiral model axioms \\
\hline Payoff for A & 3 & 7 \\
\hline Payoff for B & 3 & 7 \\
\hline
\end{tabular}

Source: The author's own creation

The moderately low payoff of 3 is indicative of the recognition by both A and $\mathrm{B}$ that neither side has an interest in unnecessary security competition. In addition, the moderately high payoff of 7 that both $\mathrm{A}$ and $\mathrm{B}$ stand to gain by adopting spiral model axioms affirms that both $\mathrm{A}$ and $\mathrm{B}$ place a higher value on long-term diplomatic and security cooperation with one another, rather than engage in unnecessary security competition with each other. Yet, it should be noted that some mistrust remains between $\mathrm{A}$ and $\mathrm{B}$, hence the recognition by both that they still stand to gain something from some level of deterrence model axioms (albeit reduced) in their interaction with one another in hedging against the possibility of renewed rivalry at a later date. Although A and B remain suspicious of one another, they have also come to recognize that they can work cooperatively with each other to advance their own long-term security interests. 
Jervis's work on security regimes is particularly illustrative. Jervis defined a security regime as 'norms and expectations that facilitate cooperation, but a form of cooperation that is more than the following of short-run self-interest' (Jervis 1982, 357). Jervis cited the post-1815 Concert of Europe as an instance of a security regime. Following the devastation of the Napoleonic Wars, the European powers feared that another major conflict was in none of their interests. Although the rival European powers continued to prioritise their own interests, they also recognised the importance of taking a longer-term view and appreciating that such interests were best served by the avoidance of conflict. During the early years of the Concert, the European powers exercised diplomatic restraint, on the grounds that this would give their partners in the Concert more of an incentive to continue to abide by its norms and thus avoid unnecessary security competition that none of them wanted (Jervis 1982, 364-65).

Although the Concert of Europe began to unravel shortly thereafter, the Triple Entente between the UK, France and Russia offers a more concrete illustration of a security regime. Although the UK was the dominant world power at the turn of the $20^{\text {th }}$ century, she faced increasing geostrategic competition from France and Russia that had also embarked on imperial expansion (Kennan 1984). Such endeavours gave rise to growing tensions over the demarcation of their empires, particularly in Africa (where French colonial expansion aroused British concerns over control of the Suez Canal) and South Asia (where Russian expansionism into Central Asia threatened British India) (Boyd 1988; Ewans 2012). These tensions included two war scares, the Fashoda Crisis of 1898 and the Dogger Bank Incident. During the Fashoda Crisis, Britain and France had nearly come to blows over the demarcation of their colonies in Africa (Bates 1984). Likewise, in 1904, Russian warships en route to reinforce the Russian Far East in the war against Japan mistook British fishing ships in the North Sea for Japanese submarines and opened fire, killing two British fishermen (Lebow 1978, 66-75). ${ }^{3}$ Yet, in spite of the fears of war during both incidents, the UK, France and Russia all chose restraint in recognition of the rising power of Germany as their common enemy. In the case of the Fashoda Crisis, not only did the opposing British and French armies exercise restraint amidst the standoff, the UK and France also agreed to use the Nile and Congo Rivers to mark their respective spheres of influence in Africa (His Majesty's Stationery Office 1909, 785-93). In the case of the Dogger Bank Incident, the British Government chose not to give in to public demands for military retaliation against the Russian Fleet (Merills 1999, 47-48), and instead brought the matter to an international court of arbitration. The Russian Government, for its part, voluntarily paid financial compensation to the families of the British seamen killed in the incident (Ibid.).

\section{CONCLUSION}


This manuscript thus underscores the case for identification of a range of possible scenario outcomes of the security dilemma. The relevance of these research findings for future research on security dilemma theory is reinforced by growing geostrategic tensions between the US on the one hand, and China and Russia on the other. In particular, although the friendly partnership between Gorbachev and Reagan in ending the Cold War was held up as an example of how the security dilemma can be mitigated between bitter rivals (Wheeler 2018, 147-78), the succession of Vladimir Putin as a strongly nationalistic President of post-Cold War Russia has led to renewed geostrategic rivalry between the US and Russia (Burns 2019). More recently, Gorbachev has adopted an increasingly hard-line nationalist position, including support for Putin's annexation of the Crimean Peninsula (Reuters 2016). Under such circumstances, it is worth considering if Gorbachev may well go down in history as anomalous instance of a leader willing to seek rapprochement with an erstwhile rival in international relations (Tan 2018, 131-32).

Whilst I do not in any way suggest that the renewed tensions amidst growing geostrategic rivalry between the US, China and Russia in the present day vindicates the inescapability of the more pessimistic scenarios outlined in this article or by offensive realist scholars such as John Mearsheimer (Mearsheimer 2001), they nonetheless reinforce the underlying challenge outlined by Herz in his exploratory works on the security dilemma (Herz 1950): in an anarchic world where states seek military self-reliance to ensure their security in an uncertain world, the armaments that they acquire can be used offensively or defensively. The impact of such developments on international relations thus underscore the observation by Booth and Wheeler that "world politics have entered a new age of uncertainty, and one whose landscape is shaped by risk, danger, mistrust, fear, uncertain cooperation, doubtful trust and insecurity' (Booth and Wheeler 2008, 266). Such a backdrop all the more underscores the importance of future research on the security dilemma and its implications in international relations.

\section{REFERENCES}

Aksenov, Pavel. 2013. "Stanislav Petrov: The Man Who May Have Saved the World.” BBC. September 26, 2013.

Bates, Darrell. 1984. The Fashoda Incident of 1898: Encounter on the Nile. Oxford: Oxford University Press.

BBC. 2018. "Trump to Kim: My Nuclear Button is Bigger and More Powerful." BBC. January 3, 2018.

Booth, Ken and Nicholas Wheeler. (2008). The Security Dilemma: Fear, Cooperation and Trust in World Politics. Basingstoke: Palgrave Macmillan.

Boyd, William. 1988. “Carving Up Africa.” New York Times. February 28, 1988. 
Braunbeck, Paul. 1997. "A Military Leadership Analysis of Adolf Hitler." (Thesis, Air University, US Air Force).

Burns, Robert. 2019. "Analysts Warn U.S.-Russia Tensions Could Spiral Into Armed Confrontation, Nuclear War." Associated Press. April 14, 2019.

Butterfield, Herbert. 1951. History and Human Relations. London: Collins.

Christensen, Thomas. 2002. "The Contemporary Security Dilemma: Deterring a Taiwan Conflict." The Washington Quarterly 4(25): 7-21.

Cohn, Marjorie. 2017. "The Duty to Disobey a Nuclear Launch Order." New Cold War. November 28, 2017.

Creekmore, Marion. 2006. A Moment of Crisis: Jimmy Carter, the Power of a Peacemaker, and North Korea's Nuclear Ambitions. New York: Public Affairs.

Dobbs, Michael. 2009. One Minute to Midnight: Kennedy, Khrushchev, and Castro on the Brink of Nuclear War. New York: Vintage Books.

Ewans, Martin. 2012. Securing the Indian Frontier in Central Asia: Confrontation and Negotiation, 1865-1895. Oxford: Routledge Curzon.

Ferguson, Niall. 2006. "Insights for Contemporary Policies." Conversations with History.

Fischer, Fritz. 1967. Germany's Aims in the First World War. London: Chatto \& Windus.

Frye, Alton. 1984. "Strategic Build-Down: A Context for Restraint." Foreign Affairs 62(2): 293-317.

Hamilton, Robert. 2018. “1983: The Year of Living Dangerously.” Foreign Policy Research Institute.

Herz, John. 1950. "Idealist Internationalism and the Security Dilemma." World Politics 2(2): 157-180.

Hertslet, Edward. 1909. “The Map of Africa by Treaty.” His Majesty's Stationery Office, London: Harrison and Sons.

Ignatius, David. 2018. "Trump Gets the Headlines on North Korea. But Keep an Eye on South Korea." Washington Post. August 2, 2018.

Jackson, Van. 2018. On the Brink: Trump, Kim and the Threat of Nuclear War. Cambridge: Cambridge University Press.

Jervis, Robert. 1976. Perception and Misperception in International Politics. Princeton: Princeton University Press.

Jervis, Robert. 1978. "Cooperation Under the Security Dilemma." World Politics 30(2): 167-214.

Jervis, Robert. 1982. "Security Regimes." International Organization 36(2): 357-378.

Jervis, Robert. 2001. "Was the Cold War a Security Dilemma?" Journal of Cold War Studies 3(1): 36-60.

Jo, Sam-Sang. 2007. European Myths: Resolving the Crises in the European 
Community/European Union. Lanham, Maryland: University Press of America.

Kennan, George F. 1984. The fateful alliance: France, Russia, and the coming of the First World War. Manchester: Manchester University Press.

Koenig, Nicole and Marie Walter-Franke. 2017. "France and Germany: Spearheading a European Security and Defence Union?” Policy Paper 202. Paris, France: Jacques Delors Institut.

Kydd, Andrew. 2000. "Trust, Reassurance, and Cooperation.” International Organization 54(2): 325-357.

Lebow, Richard Ned. 1978. "Accidents and Crises: The Dogger Bank Affair." Naval War College Review 31(1): 66-75.

Lee, Jae Seung. 2004. "The French Road to European Community: From the ECSC to the EEC (1945-1957)." Journal of International and Area Studies 11(2): 107-123.

Lynn-Jones, Sean. 1995. "Offense-Defense Theory and Its Critics." Security Studies (4)4: 660-691.

McMeekin, Sean. 2013. July 1914: Countdown to War. London: Icon Books.

Matlock, Jack. 2004. Reagan and Gorbachev: How the Cold War Ended. New York: Random House.

Mearsheimer, John. 2001. The Tragedy of Great Power Politics. Chicago: W.W. Norton.

Merrills, J.G. 1999. International Dispute Settlement. Cambridge: Cambridge University Press.

Muller, Richard. 2004. "The Origins of MAD: A Short History of City-Busting." In Getting MAD: Nuclear Mutual Assured Destruction, Its Origins and Practice edited by Henry Sokolski. Pp. 15-50. Carlisle, Pennsylvania: US Army Strategic Studies Institute.

Nalebuff, Barry. 1986. "Brinkmanship and Nuclear Deterrence: The Neutrality of Escalation.” Conflict Management and Peace Science 9(2): 19-30.

Oberdorfer, Don and Robert Carlin. 2014. The Two Koreas: A Contemporary History. New York: Basic Books.

Polmar, Norman and John D. Gresham. 2006. DEFCON-2: Standing on the Brink of Nuclear War During the Cuban Missile Crisis. Hoboken, New Jersey: John Wiley and Sons.

Princen, Thomas. 1995. Intermediaries in International Conflict. Princeton: Princeton University Press.

Reuters. 2016. "Ukraine Bans Gorbachev Over Support for Crimea Annexation." Reuters. May 26, 2016.

Ripsman, Norrin. 2005. "Two Stages of Transition from a Region of War to a Region of Peace: Realist Transition and Liberal Endurance." International Studies Quarterly 49(4): 669-693. 
Salmon, Andrew. 2019. "Hanoi Summit Ends Early With No Agreement." Asia Times. February 27, 2019.

Schelling, Thomas. 1966. Arms and Influence. Yale: Yale University Press.

Schlosser, Eric. 2018. "Ban the Bomb: How the Treaty on the Non-Proliferation of Nuclear Weapons Helped Prevent Annihilation." The Globe and Mail. June 8, 2018.

Snyder, Scott and See-Won Byun. 2018. "Moon's Olympic Diplomacy." Comparative Connections 20(1): 85-95.

Tharoor, Ishaan. 2015. "In Defense of Neville Chamberlain, Hindsight's Most Battered Punching Bag." Washington Post. July 20, 2015.

Thornton, Bruce. 2011. The Wages of Appeasement: Ancient Athens, Munich, and Obama's America. New York: Encounter Books.

Tuchman, Barbara. 1962. The Guns of August. New York: Random House.

Van Evera, Stephen. 1984. "The Cult of the Offensive and the Origins of the First World War." International Security 9(1): 58-107.

Wheeler, Nicholas. 2018. Trusting Enemies: Interpersonal Relationships in International Conflict. Oxford: Oxford University Press, 2018.

Wit, Joel, Daniel Poneman and Robert L. Gallucci. 2004. Going Critical: The First North Korean Nuclear Crisis. Washington DC: Brookings Institution Press..

\section{ENDNOTES}

1 Although Britain was a member of the Triple Entente with France and Russian and joined them during the war, the UK had no alliance obligation to its Entente partners, and maintained a largely ambivalent position for much of the July Crisis.

2 Transcendence of the security dilemma corresponds to a security community whose members have a shared identity of each other as friends rather than competitors. This marks a level of interaction that goes well beyond an interaction between self-interested rational egoists, hence the absence of such a matrix in this section of the article.

3 The Dogger Bank Incident was particularly serious given that in 1902, the UK had entered into an alliance with Japan, primarily to form a potential coalition against the contingent scenario of Russian expansionism in Asia. 